\title{
EXPLORING USEFULNESS OF CRM AND IT IN MALAYSIAN HOTEL INDUSTRY: A QUALITATIVE APPROACH
}

\author{
Mohamad Ghozali Hassan', Fawad Hussain² \\ and Mihraj Begum Saibu Rahman ${ }^{3}$ \\ ${ }^{1}$ School of Technology Management \& Logistics \\ UUM College of Business, Universiti Utara Malaysia, \\ 06010 Sintok, Kedah, Malaysia \\ ${ }^{2}$ Pakistan Air Force, Karachi Institute of Economics and Technology \\ Karachi, Pakistan \\ ${ }^{3}$ Open University Malaysia, Pulau Pinang Learning Center, \\ Penang, Malaysia \\ Corresponding author:ghozali@uum.edu.my
}

\begin{abstract}
Today, the hotel industry is deviating from their traditional way of doing business and is now becoming more customers focused aimed at developing a positive and satisfying relationship with their customers. Information technology (IT) is the most significant factor that is helping the management of hotel industry to lower costs, increase operational excellences with profitability and give value to customer's time. Malaysian hotel industry is based on Malaysian customer, culture involving a specific way of treating customers. The competitive advantage in this industry is based on the time and cost factors, which worries the customer and the hotel management. Information technology has helped the entire industry to prevent the wastage of resources and time by fulfilling optimum customer needs and demands. This paper is an attempt to explore the customer relationship management and IT related issues in three star rated hotels in the state of Penang, Malaysia. This paper would contribute as a useful guide to three star hotels, giving them some valuable information on what the customer expectations are in terms of CRM and IT facilities and if they are duly met then services and operational issues shall not occur. The significance of this case study includes providing a scope for three star rating hotels to improve their IT based
\end{abstract}


activities to influence service quality and reduce the weaknesses, through availing opportunities and to strengthen their position in the industry.

Keywords: CRM, customer satisfaction, expectations, loyalty and Malaysian three star hotels.

\section{INTRODUCTION}

Hotel industry is based on those businesses which lead to profitability only because of their customer service, customer loyalty and customer satisfaction. Like other industries, this industry has also deviated from its traditional way of doing business and is actually now becoming more customer-focused and aimed at developing a positive and satisfying relationship with their customers. There is huge interference of Information technology and it underpins the reason for efficiency, meeting customer expectation and accuracy in services. Information technology is the most significant factor that is helping management of hotel industry in lowering their cost, time accuracy and increasing the operational excellences. Malaysian hotel industry is based on Malaysian customers' culture involving a specific way of treating customers.

This paper is a qualitative analysis based on customer relationship management (CRM) and Information technology (IT) practices of the Palm Inn Hotel. There are three branches of Palm Inn Hotel. One of it is in Kuala Lumpur and two in Penang, located in Butterworth and Bukit Mertajam. In the present case, this paper conducted interviews of IT manager of Butterworth Branch Palm Inn Hotel and Kuala Lumpur branch. The first Palm Inn Hotel was opened in Ampang, Kuala Lumpur in August 2005 with 35 rooms in 3 floors. The second Palm Inn Hotel was opened in September 2008 with 42 rooms in 5 floors and the third one was opened in November 2008 with 90 rooms in 6 floors. The management of Hotel Palm Inn will be opening a 20-storey Business class Hotel in 2014 under different brand strategy, in Seberang Jaya Penang.

According to Mr. Paul, (IT Manager, Penang branch), when the first branch was opened, the hotel did not increasingly make use of IT software. IT was only prevalent in the form of Hotel Web Page, CCTV, IPTV, Security Alarm System and Point of Sale System were used. For the second and third branches, more IT software were installed such as Keycard System, Telephone with multi core PABX systems, Free WIFI, and Online Guest Reservation, Confirmation and Cancellation Software. They did not have Customer Relationship Management Software. It was later installed based on the recommendation by the IT depart, 
which was later benefited from especially in the fourth hotel which is planned to have 20 floors and 276 rooms. This paper aims to explore Palm Inn Hotel's customer complaints and expectations in term of CRM and weakness of IT.

\section{BENEFITS OF INFORMATION TECHNOGLOGY}

Recent trends in globalization and advancement in information technologies have enabled businesses to explore new directions in their competitive markets. In many industries today, information system administrators carry out these setups. Globally the trend is deviating strategically as the managers' look forward to adjust the technological changes according to latest advancements and market trends. The aim of these managers is to get the most out of strengths, deal with threats and decrease weaknesses.

In the hotel industry, there is high competition and the industry is trying to provide and fulfill the best demands and expectations of their customers (Wahid, Dahalin, Idrus, \& Omar, 2010). Customers nowadays have the alternative to buy what they think they should and from whom, being in their best interest, so they have many options and choices. In the hotel industry, the management needs to follow the trend and fashion of product development, technological improvement, cost optimization and excellent service facility, which are very important for any hotel but their significance only matters when customer appreciates it. The competition never stops, with increasing competitiveness; hotels are worried of the degree of customer satisfaction and their profitability in both short- and long-term. It is very important that hotels care for their long run profitability, which can be achieved through CRM and effective management strategies to ensure customer satisfaction and loyalty. Customer expectations are always demanding for a newer benchmark within the industry. Therefore, the competitive pressures are demanding for hotels not only to accept the customer oriented CRM strategy, but also to follow customer concerned procedures of performance (Nor Aziah \& Minai, 2009).

Information technology enables hotels to acquire the capability to process huge amount of information and present it in an understandable and brief manner to employees for further decision-making (Najafabadi, Hosseini, \& Mirdamadi, 2009). Predictable advantages of implementing an information technology system include enhancements in productivity, improving profit or return through performance, and maximization of accuracy within the organization, which is interconnected through information. The capability to share information among employees is also improved with IT (Karimi, Somers \& Gupta, 2001). 
Information technology has become a revolution in the industry and personal computers are often linked together across wide geographic areas to create networks. When we use this informative technological advancement, it offers added payback to hotel performance and operational excellences, such as data integrity and enhanced performance. By using a broadband network, users can share a greater range of voice, data and video services, including videoconferencing. Technology has kept up with advancements in hardware and software as to influence productivity, which makes it easy to incorporate into operational activities (Anckar \& Walden, 2001).

\section{CUSTOMER RELATIONSHIP MANAGEMENT}

Customer relationship management is defined as "a managerial philosophy that calls for the use of information technology (IT) to capture, store, manipulate and distribute substantial information about customers." (Piccoli, Connor, Capaccioli, \& Alvarez, 2001). The term Customer Relationship Management (CRM) is explained as "the core business strategy that integrates internal processes and functions, and external networks, to create and deliver value to targeted customers at a profit. It is grounded on high-quality customer data and enabled by IT”(Buttle, 2004; Jaipuria, 2009).

In another respect, CRM is a specific organizational strategy to know or to identify, cultivate, and maintain long-term profitable customer relationships. It is needed to establish a technique to choose the most potential customers and to provide those customers with excellent service quality that exceeds their expectations leading to customer satisfaction and loyalty (McDonald, 2002; Jaipuria, 2009).

\section{CUSTOMER SATISFACTION AND LOYALTY}

Hotel performance appreciates when there are high valued customers and therefore the aim of any hotel management is to have an efficient CRM practices. These CRM practices can be improved by enhancing customer satisfaction and customer loyalty as shown by Buttle (2004) presented in Figure 1. Buttle (2004) explains that customer satisfaction and their loyalty is the key competency for any hotel business (Jaipuria, 2009). On the other hand the most widely used model, is the "satisfaction-profit chain" (Anderson, \& Mittal, 2000; Jaipuria, 2009). 
It is found that satisfaction increases as customer insight permits hotels to understand their customer better, and create a better improved understanding of customer value propositions. It is mathematically represented as, with the increase in the satisfaction of customers, the customers' buying power or intention also appreciates (Anderson, 1994). These variables are highly significant to influence the customer's basic purchasing behaviour or mentality, which has a value adding impact on hotel performance (Jaipuria, 2009).

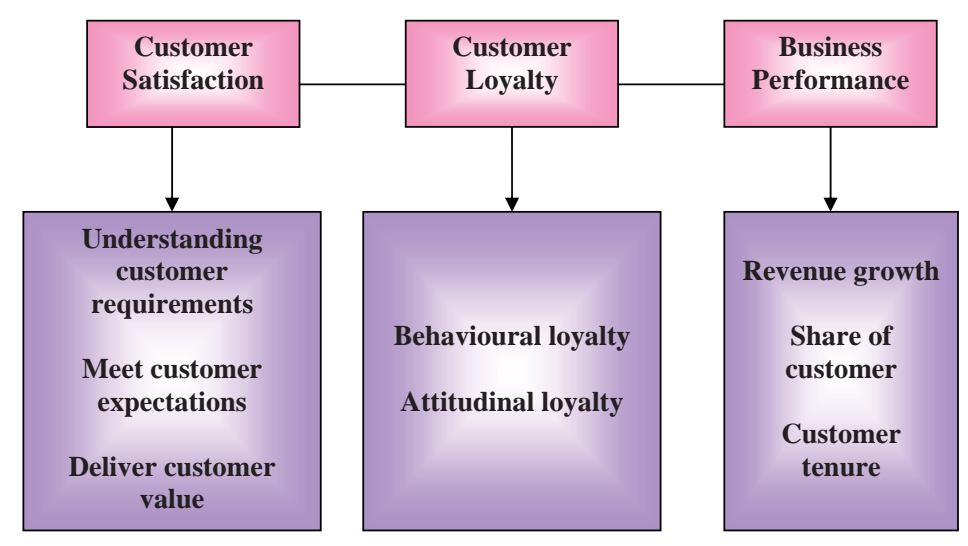

Figure 1. Customer satisfaction, customer loyalty and hotel performance.

Source: Buttle, 2004; Cited in, Jaipuria, 2009.

On the other hand, customer loyalty can be explained in dual distinct directions (Jacoby \& Kyner, 1973). The first distinct direction explores loyalty as an attitude. The number of different feelings makes a customer attached to a specific service, product or a hotel (Fornier, 1994). The feelings are explained as individual or customer's degree of loyalty. The second distinct direction explores loyalty as a behaviour. The behaviour attributes includes pushing an individual or customer to buy the product or services from the same service or product provider (Yi, 1990; Jaipuria, 2009).

\section{CUSTOMER EXPECTATIONS AND PERCEPTIONS}

There are many views of how researchers perceive customer expectations and their perceptions. As discussed by Parasuraman et al. (1985), customer expectations are in the form of expected service quality and perceived service quality. He has proposed a model known as the gap model which states that there are five gaps. 
These gaps explain the customer expectations and perceptions from both the customer and the hotel. The model is divided into two parts as shown in Figure 2. On the first level it explains how the service emerges from the customer's perspective. In the second part it explains the service provider's perspective towards the customer. The first gap shows the management perception, which occurs when the management perceives the quality expectations inaccurately due to inaccurate interpretation of information from the market research and demand analysis. The second gap explains the quality specification and the service quality descriptions, which are not consistent with management perceptions of quality expectations due to planning, unclear goal, the setting within the hotel and insufficient planning support from top management. The third gap indicates the quality specifications, which are not met by performance of hotel in the service production and delivery process due to the specifications' complex and unfixable features. The fourth gap indicates that the promises are inconsistent with the service delivered. So there is variation between what is promised and what is provided. The fifth gap explains the perceived service quality and it shows the importance of the inconsistency between perceived or experienced service and the expected service, which results in a negative impact upon the corporate brand or image and the firm eventually loses some portion of business (Jaipuria, 2009).

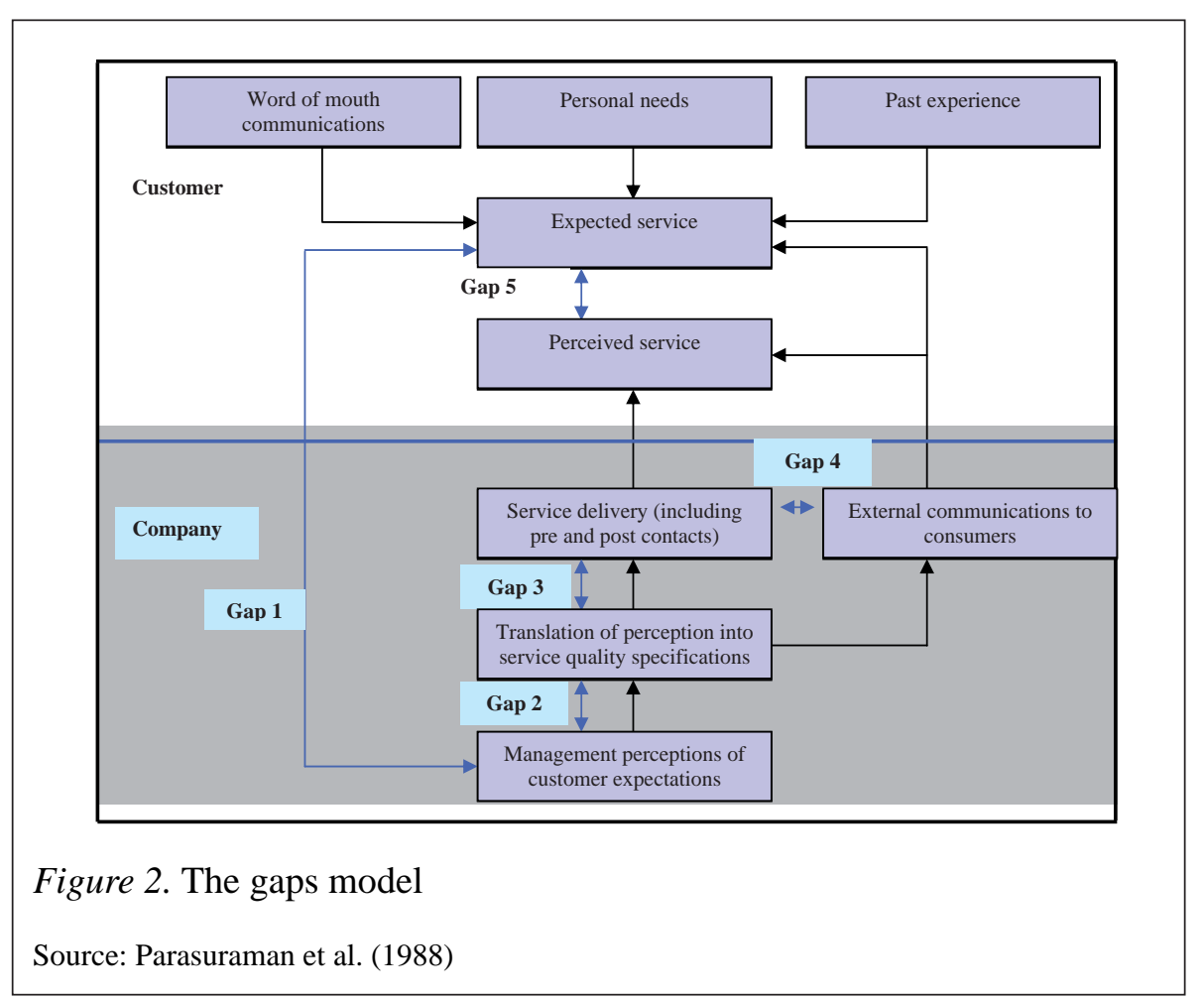




\section{INFORMATION TECHNOLOGY IN HOTEL CONTEXT}

The electronic interaction and distribution to strategically integrated different levels and units of any hotel can explain information technology in hotel context. In line with a similar definition Dale (2003), has explained that it is very difficult to explain electronic distribution within the hotels. He further added that the in a competitive business environment, hotels are only competitive or maintain their competencies, when they assure stable inter-organizational relationship electronically. Information technology is a revolution in the hotel industry. It sets up customer information system (CIS) that automates information exploration and dispensation and makes available a reliable observation of the customer all over at every point of interaction, bringing together a broad array of data into an actionable set-up that helps management decision making (Kasim, 2008). The CIS is based on a data warehouse with an accessible and user-friendly interface helps integrate different operational systems and databases and enables multi level storages and profiles for the same customers, based on their way of behavior and level within the list of customers (Minghetti, 2003).

In addition, relationship orientation involves business or hotel customer intelligence - it is the competency to know customers' needs, behavior, and preferences, recognize the most important customer part and to make the most of profit resulting from each of them (KPMG, 2001; Minghetti, 2003; Nykamp Consulting Group, 1999).

\section{COMPLAINTS FACED BY IT MANAGERS}

\section{Pricing issue}

In this study managers have indicated that the pricing is the sole factor, which attract or distract customers towards a hotel. In a similar manner Enz (2003) and Dale (2003) also address the issue of the networks identified by Dale (2003) as those driving down hotel profitability. Noting that hoteliers use these networks without a clear understanding of their effect, she claims that they encourage competition based solely on price and urges a rethink of such hidden discounting.

\section{Information technology frauds}

It is true that information technology is very useful but at the same time it has also given space to cyber crime. Likewise hotel industry has become more dependent on information technology resources as a means 
of increasing customer and their staff's easy retrieval of information through program and services, and in return maximizing profitability. As mentioned by many researchers and academicians, information technology system has a positive impact on the development and growth of hotels. On the other hand, it is very common for organizations to face risk and fraud through these resources (Behling, Floyd, Smith, Koohang, \& Robert, 2009).

This study investigates some customer complaints concerning information system frauds, especially in booking and cancellations. In this regard, the hotel management needs to design an operational strategy and authentication of web sites, which are authorized for booking. This study reports that there is an urgent need for protecting customers from scamming.

\section{Complaints for price variation}

The qualitative data of this study from hotels conclude that online prices are comparatively lower than those offered through online booking web sites such as Hotels.com. It is also found that respondents reported that when they proceed for the cancellation while calling the hotel or booking people they are directed to the hotel's customer service and after entering all information and pressing submit, the customer receives the response to their request. Enzi (2003), Dale (2003), Connor and Murphy, (2004) also discussed similar issues and stated that customers face problems while booking and then cancelling the same booking.

\section{Complaints for online transaction}

It is also reported that respondents cancelled the booking but was charged double the price upon notification through the letter from AMEX (Credit Card Billing), which stated no refund due. So the customer was charged doubled for the same hotel for the same dates on their AMEX statement. On the similar issue Schegg and Murphy (2003) stated that technology is not integrated with manual booking and there is a variation in the customer's booking online that is not shown on their manual transaction but is reflected in their credit card billings as double charge.

\section{Complaints for online booking scams}

Nowadays there are number of internet scams sending discounted offers and asking for personal information such as Credit Card number, passwords and identity card (IC) number. Providing such personal information is never a healthy exercise and it causes a huge financial loss. 
During our interview with the respondents, we came to know that apart from location and other attractions; the hotels have no strategy as how to treat customers with courtesy and respect. As when a complaint was lodged for a booked room through Hotels.com.my, provided with confirmation, but eventually turned out to be a scam, when the respondent reached the hotel, the customer was declined a booking even when he showed the confirmation print out. According to Jeong et al. (2003), the role of online information and behavioral intention, highlights the significance of information satisfaction. They assert that this is an influential determinant of behavioral intentions and service providers must ensure that websites satisfy visitors' information needs in order to expect online transactions (Conor, \& Murphy 2004).

\section{Complaints for late reply and unethical attitude}

The analyses showed that frequent delays are experienced by customers in answering a specific question or query. The customer service keeps asking the customer to wait and by that time they already solved the issue to their favor.

\section{Complaints for walk-in and online booking}

It is also recorded that a walk in customer was charged less than those booking via online services or third party reservations. The customer reported that booking through the hotel counter is cheaper than those booking through online third party websites. After they charged the customer's credit card, the customer asked for a printed receipt. Then the customer found out that the hotel's cost was way cheaper than what is shown on web sites such as Hotels.com.

\section{Complaints regarding reservation date}

It is also recorded that there were hotel respondents who made a mistake typing in the date of reservation through the website. The customer called two times, and his request to talk to a superior was refused by the mediating people. Therefore, the customer was left to complain to the front office desk and was assured of the solution to the problem. Upon confirming with Hotels.com, the customer was assured the second time. When the time came for the customer to avail of the hotel's services, the room was not booked and the customer had to leave the premises.

\section{Complaints of cancellation and reservation issues}

In the given study, respondents from the hotel found that the customers are facing problems while canceling the reservations because of the hotel's 
failure to answer the phone whereby the customer realized that he was being scammed. The customer immediately called AMEX to register a dispute of the charge and they initiated the investigation.

\section{Complaints of third party booking issues}

It is also found that a hotel customer involved in third party contract faced problems. In the given case, the customer simply needed a detailed receipt to claim travel or lodging at work. The hotel they stayed at could not give them a receipt because it was booked through a third party.

\section{Complaints of double booking issues}

The qualitative data indicated that Expedia somehow double booked a reservation for a customer. In most cases, the customers come with a budget and in cases like this, they cannot afford to pay. The Expedia web site official claimed that the fault is at the customer's end, but the customer did not receive a follow-up confirmation email and his credit card was charged. The question is why would someone book a reservation at two different hotels on the same night in the same place? Expedia did not help the customer but instead claimed typo error or double booking relegating the matter as the customer's problem. So this situation made a bad impression of the Expedia website.

\section{Complaints for over pricing a room that is tagged best prices online}

This study also came to know that the customer booked a room in the hotel. Expedia guaranteed the best price, and the customer credit card was duly billed. A few weeks later, when the customer arrived and checked in, he stayed at a less than advertised hotel and when he checked out the next day, the bill from the hotel was several ringgits less than Expedia charges. In other words, the customer could have purchased the room cheaper by going directly to the hotel. The customer was recorded as saying that customer service only repeated the same thing over and over again and never listened to the problem. The customer eventually reported that they would never recommend this company to anyone for any reason.

\section{MANAGEMENT PERSPECTIVE OF COMPLAINTS}

The management perspective of customer complaints is that may not know who to complain to. Customers complain under one or both circumstances: their prospect being underperformed to an extent that falls outside their zone 
of tolerance, or unfair treatment. Table 1 shows the hotel management's perspectives of complaints.

Table 1

Complaints from Management Perspective

\begin{tabular}{|c|c|}
\hline \multicolumn{2}{|c|}{ COMPLAINTS FROM MANAGEMENT PERSPECTIVE } \\
\hline $\begin{array}{l}\text { Hotel Customers do not know how to } \\
\text { register a complaint }\end{array}$ & $\begin{array}{l}\text { Hotel Customers believe complaining will } \\
\text { be useless because the company doesn't } \\
\text { care about them or their complaints. }\end{array}$ \\
\hline $\begin{array}{l}\text { Hotel Customers believe it is not } \\
\text { worth the time or trouble }\end{array}$ & $\begin{array}{l}\text { Hotel Customers fear retribution. For } \\
\text { example, many people are reluctant to } \\
\text { complain to the police. }\end{array}$ \\
\hline
\end{tabular}

Source: Wilson (1991) and Buttle (2005)

It is clear that the hotel is desirous to establish relationships with customers, but it is far less clear if customers universally want to establish relationships with their service providers - which in the given case are hotels. In the similar direction, managers face difficulties to make their customers satisfied and loyal. In the context of hotel management, the managers need to seek their customer's feedback to take obtain of recognition, personalization, power, risk reduction, status and affiliation (Buttle, 2004). For example if we take Tesco loyalty cards, Hilton honors program, British Airways frequent flyer cards, etc. , the hotels can likewise allocate some benefits to their repeating or frequent customers and collect data like contact name, history of purchase, money spent in the past on company's services, etc. On the other hand, if the data is mismanaged or improperly handled, it can destroy the customer's satisfaction, trust and loyalty in the relationship (Vargas, 2006).

\section{STRENGTHS AND WEAKNESSES OF SURVEY}

Table 2 shows the strengths and weakness of survey and Table 3 shows the details of interviews.

\section{Sampling}

The study was based on three stars rated hotel in Penang and Kuala Lumpur Malaysia. The total sample contains thirty-three people comprising twenty businessmen, eight tourists and five families. The study also interviewed the hotel manager and the hotel IT manager. 
Table 2

Strengths and Weakness of the Survey

\section{STRENGTHS}

\section{WEAKNESSES}

- Customers and employees are targeted $\bullet$ The Interviews were conducted in to obtain a better focus of the case limited time. study topic.

- Bias in interview questions and

- The case study report provides insight and tries to cover complaints as maximum as possible. answers.

- Response bias.

- The interviews are based on reality.

- Interviewee expresses what interviewer wants to hear.

- 33 out of 50 questionnaires were collected from the hotel customers.

- Survey is very limited to one hotel.

- Time-consuming.

- Managers feel hesitant to divulge actual problems faced in the hotel.

Table 3

Details of Interviews

\begin{tabular}{ll}
\hline \multicolumn{1}{c}{ Customer Interviewed } & \multicolumn{1}{c}{ Staff interviewed } \\
\hline $20-$ Businessman & $1-$ Hotel Manager \\
$8-$ Tourist & $1-$ Hotel IT manager \\
$5-$ Family & TOTAL: 2 People \\
TOTAL: 33 People & \\
\hline
\end{tabular}

DATA ANALYSIS

The interviews were analyzed to address the initial propositions of a study, which is based on CRM and IT practices in hotels. The methodology is based on in-depth interviews, which is the instrument used in the case study report to achieve its objectives and propositions, to help structure the analysis and provide in-depth understanding on CRM and IT factors that help hotel management maximize profits. The interview data was analyzed in depth to interpret the customers' perspective and managerial perspective regarding the CRM and IT facilities. 


\section{RECOMMENDATIONS}

In the future, more researchers are needed to explore avenues of CRM in connection with IT and their usefulness in Malaysian hotel industry. Specifically, in the hotel industry, CRM is changing and becoming a strategic essential element for attracting and increasing guests' patronage (Sigala, 2005). There is sufficient literature available on IT, CRM and hotel industry. This is an open opportunity for students and researchers to find more factors like hotel culture, pricing, branches and location, which can help management to increase their customers - the hotel's success factor.

\section{SUGGESTIONS}

This study suggests that hotel management must learn from their customer dealings and feedbacks. It also needs to flatten its hierarchical structure to sum up what is expected by the customer and what is delivered on the record. On the other hand, market research is another strategy, which would help the hotel management to improve in terms of knowledge and service competition. The study also suggests that hotels to change their priorities and show a strong commitment to developing service standards, to do a feasibility assessment of customer expectations and to develop a standard documentation process and automation of processes wherever required. The hotel management also needs to develop their service-oriented goals. In the researchers' opinion, the hotel should invest in people through the provision of staff training, recruitment and retention. Moreover, it is also imperative that the hotel management keep updating and investing in technology in order to meet the technological challenges. It is also required for the management to redesign workflow from time to time and encourage the staff by rewards and recognition that will improve the internal confidence of the hotel staff when dealing with customers. An improved internal communication is a must and in addition, hotel management should provide clear job specifications to avoid any uncertainty or ambiguity. The best way for the management to learn is to pay constant consideration to customer complaints and feedbacks. This could help the management not only to improve their services but also to improve quality and evaluate its weaknesses.

\section{CONCLUSION}

The analysis of this study has shown that CRM implementation and practices are suitable with the presented strategies of these hotels in order to accomplish their most important aims. In comparison with other findings, we came to 
know that performance is appreciated as CRM practices involves the ongoing process development of market intelligence for building and maintaining a profit-maximizing portfolio of customer relationship (Nor Aziah and Minai, 2009; Zablah et al., 2004). As mentioned earlier, the trend in hotel industry is deviating from its traditional way of doing business and is now actually becoming more customers focused. The term focus can be explained in this context as customer satisfaction, loyalty and their preference. Information technology is the most significant factor that is helping the management of hotel industry to lower costs and give value to customers. As the market is very competitive, any negligence will never be tolerated neither by the customer nor the hotel management. The hotel management must carefully satisfy the expectations of their customer and make a positive long-term relationship. The hotel management also needs to develop their service-oriented goals. The more the services are offered, the more the customer will return for repetitive patronage. Managers need to face and solve the complication and difficulties to gain customer satisfaction and loyalty.

\section{REFERENCES}

Anderson, E.W. (1994). Cross Strategy variation in customer satisfaction and retention. Marketing Letters, 5(Winter), 19-30.

Anderson, E.W., \& Mittal, V. (2000). Strengthens the satisfaction-profit chain. Journal of Service Research, 3(2), 107-120.

Akshay Jaipuria. (2009). The dark side of customer relationship management in the luxury segment of the hotel industry (MA Management Dissertation). University of Nottingham.

Anckar, B., \& Walden, P. (2001). Introducing web technology in a small peripheral hospitality organization. International Journal of Contemporary Hospitality Management, 13(5), 241-250.

Buttle, F. (2004). Customer relationship management: Concepts and tools. Oxford: Elsevier Butterworth-Heinemann

Dale, C. (2003). The competitive networks of tourism E-mediaries: New strategies, new advantages. Journal of Vacation Marketing, 9(2), 109-118.

Enz, C. (2003). Hotel pricing in a networked world. Cornell Hotel and Restaurant Administration Quarterly, 44(1), 4-5. 
Fornier, S. (1994). A Consumer-based relationship framework for strategic brand management (Unpublished doctoral dissertation). University of Florida.

Jacoby, J., \& Kyner, D.B. (1973). Brand loyalty versus repeat purchase behavior. Journal of Marketing Research, 10(1), 1-9.

Jeong, M, Oh, H., \& Gregoire, M. (2003). Conceptualizing web site quality and its consequences in the lodging industry. International Journal of Hospitality Management, 22(2), 161-1775.

Karimi, J., Somers, T. M., \& Gupta, Y.P. (2001). Impact of information technology management practices on customer service. Journal of Management Information, 17(4), 125 - 158.

Kasim, R. S. R. (2008). The Commercialisation of knowledge management practices to K-based development in Malaysia. Journal of Information and Communication Technology, 7, 57-72.

KPMG. (2001, November). CRM and the global travel industry. Retrieved from http://www.kpmg.co.uk/kpmg/uk/DIRECT/INDUSTRY/ICE/ TRAVEL/ index.cfm.

Najafabadi, M. O., Hosseini, S. J. F., \& Mirdamadi, S. M. (2009). An ordinal factor analysis of requirements and challenges of information and communication technology system to train private agricultural insurance brokers in Iran. Journal of Information and Communication Technology, 8, 103-114.

Nykamp Consulting Group.(1999). CRM Not an evolution but a transformation. Retrieved from http://www.eyefortravel.com/ pastevents/crm/program. html

McDonald, L. (2002). Customer relationship management - An overview Retrieved from http://www.brillianceweb.com/betterwebdesign/tips_ 48.aspx

Nor Aziah Abu Kasim, \& Badriyah Minai. (2009). Linking CRM strategy, customer performance measures and performance in the hotel industry. International Journal of Economics and Management, 3(2), 297 - 316.

Parasuraman, A., Zeithaml, V.A., \& Berry, L.L. (1985). A conceptual model of service quality and its implications for future research. Journal of Marketing, 49 (Fall), 41-50. 
Parasuraman, A., Zeithaml, V.A., \& Berry, L. L. (1988). SERVQUAL: A multiple-item scale for measuring consumers' perceptions of service quality. Journal of Retailing, 64(1), 22-37.

O’Connor, P., \& Murphy, J. (2004). A review of research on information technology in the hospitality industry. International Technology in the Hospitality Management, 23(5), 473- 484.

Piccoli, G., O’Connor, P., Capaccioli, C., \& Alvarez, R. (2003). Customer relationship management - A driver for change in the structure of the U.S. lodging industry. Cornell Hotel and Restaurant Administration Quarterly 44(4),1-73.

Schegg, R., J., \& Murphy, et al. (2003). Five-Star treatment? E-mail customer service by international luxury hotels. Information Technology and Tourism, 6(2), 99-112.

Sigala, M. (2005). Integrating customer relationship management in hotel operations: Managerial and operational implications. International Journal of Hospitality Management, 24(3), 391 - 413.

Behling, S., Floyd, K., Smith, T., Koohang, A., \& Behling, R. (2009). Managers' perspectives on employee information technology fraud issues within companies or organizations. Issues in Information System, 10(2),76-81.

Valeria Minghetti, (2003). Building customer value in the hospitality industry: Towards the definition of a customer-centric information system. Information Technology \& Tourism, 6(2),141-152.

Juliana Wahid, Zulkhairi Md Dahlin, Mohd. Rushdi Idrus, \& Mohd Adan Omar (2010). Computer aided tool support (CATS) for Information Strategy Planning (ISP): Generating application portfolio for business area analysis. Journal of Information and Communication Technology, 9, 1-16.

Wilson. J.R. (1991). Word of mouth marketing. USA: John Wiley \& Sons.

Yi, Y. (1990). A critical review of consumer satisfaction. In V. Zeithaml (Ed.), Review of marketing (pp. 68-123).Chicago, IL: American Marketing Association. 
Zablah, A.R., Bellenger, D.N., \& Johnston, W. J. (2004). An evaluation of divergent perspectives on customer relationship: Towards a common understanding of an emerging phenomenon. Industrial Marketing Management, 33(6), 475 - 48. 